e-ISSN: 2722-0966

Vol. 2 Issue 1

\title{
Chitosan from milkfish (Chanos chanos) scales and tiger shrimp (Panaeus monodon) shells wastes as corrosion inhibitor on ASTM A36 steel
}

\author{
Chandra Silvia ${ }^{*}$, Misbakhul Munir, and Dian Sari Maisaroh \\ Marine Science Department, Faculty of Science and Technology, UIN Sunan Ampel Surabaya, Indonesia \\ E-mail: chandrasilvia9@gmail.com
}

\begin{abstract}
Chitosan synthesized from milkfish (Chanos chanos) scales and tiger shrimp (Panaeus monodon) shells were used as corrosion inhibitors on ASTM A36 steel. Milkfish scales and tiger shrimp shells wastes is extracted into chitosan through deproteination, demineralization and deacetylation process. The yield of milkfish scales and tiger shrimp chitosan was $31,81 \%$ and $67,16 \%$, respectively. Corrosion rate testing using weight loss method then calculates inhibition efficiency of each inhibitor. The immersion test of specimens was carried out for four weeks with weight measurements every week. The concentrations used were 0 ppm as negative control; $60 \mathrm{ppm}, 500 \mathrm{ppm}$ and $1000 \mathrm{ppm}$ for chitosan inhibitor; and 1000 ppm sodium nitrite as positive control. Inhibition efficiency values produced by milkfish scales chitosan, starting from the first to the fourth week immersion, for concentration of $60 \mathrm{ppm}$ were $43.9 \%, 46.8 \%, 48.9 \%$, and $40.8 \%$; for concentration of $500 \mathrm{ppm}$ were $43.6 \%, 43.3 \%, 37.8 \%$, and $17.8 \%$; and for concentration of $1000 \mathrm{ppm}$ were $37.5 \%, 44.9 \%, 39 \%$, and $21.8 \%$; while for tiger shrimp shells chitosan for concentration of $60 \mathrm{ppm}$ were $37.6 \%, 51 \%, 34.6 \%$, and $28.5 \%$; for concentration of $500 \mathrm{ppm}$ were $57.7 \%, 38.2 \%, 37.7 \%$, and $19.6 \%$; and for concentration of $1000 \mathrm{ppm}$ were $48.6 \%, 41.2 \%$, $37 \%$, and $21.3 \%$. Comparison of inhibition efficiency between chitosan from milkfish scales and tiger shrimp shells based on the statistical analysis One Way ANOVA resulted in a sig $>0.05$ which indicates a similarity in the efficiency value of chitosan from milkfish scales and tiger shrimp shells.
\end{abstract}

Keywords: chitosan, milkfish scales, tiger shrimp shells, corrosion inhibitor, ASTM A36.

\section{INTRODUCTION}

The fishery product processing industry generally produces waste that is not fully utilized. Processing of fishery products such as milkfish products without thorns has processing procedures, such as removing scales, splitting and washing [1]. Fishery products in the form of shrimp also have special processing procedures so that product quality is maintained. Generally, the shrimp to be exported will go through a series of processes before being shipped. The series of processes such as washing, cutting heads, size sorting, stripping, immersion with solutions, freeze and checking in each process [2]. This results in waste in the form of fish scales and shrimp carapace, therefore it is necessary to treat the waste.

ASTM A36 steel (a type of low carbon steel) is one type of material that is often used as raw material for equipment in various industries because of its relatively cheap price and good tensile properties. The main problem in using mild steel is when the steel is in contact with an aqueous environment, especially in the medium (solution) which is acidic [3]. This condition makes the resistance properties of mild steel become weak so it is easy to experience corrosion

Efforts to maximize the use of steel are by preventing or reducing the rate of corrosion. One method to reduce the rate of corrosion is the use of a corrosion inhibitor. Corrosion inhibitors are chemical substances that are added to an environment in order to reduce the corrosion rate of metals [4].

One of the natural ingredients that can be used as a natural inhibitor is chitosan and its derivatives [5]. Fishery waste in the form of fish scales and shrimp shells has many benefits, such as milkfish scales which are a source of chitin and chitosan [6]. The results of research by Harmami, et al. (2019) showed that shrimp shells contain chitosan which can inhibit the corrosion rate of tinplate in $2 \% \mathrm{NaCl}$ solution [7].

The level consumption of milkfish and tiger shrimp in the community is quite large, resulting in waste that is not used optimally. Milkfish scales and tiger shrimp shells wastes can be used as useful products. In this research, chitosan from milkfish scales and tiger shrimp shells wastes would be syntesized as corrosion inhibitor on ASTM A36 steel in corrosive media in the form of a mixture of $3.5 \%$ sodium chloride $(\mathrm{NaCl})$ solution and acetic acid $\left(\mathrm{CH}_{3} \mathrm{COOH}\right) 3 \%$. Chitosan performances as corrosion inhibitor were evaluated by weight loss method.

\section{RESEARCH METHODS Materials}

Milkfish scales and tiger shrimp shells waste was collected from Kalanganyar village, Sedati district, Sidoarjo. ASTM A36 steel, sodium hydroxide $(\mathrm{NaOH})$, hydrochloric acid $(\mathrm{HCl})$, aquadest, sodium chloride $(\mathrm{NaCl})$ 
acetic acid $\left(\mathrm{CH}_{3} \mathrm{COOH}\right)$, sodium nitrite and wipes was used in this study

\section{Research Stages}

Stages of this research were preparation of tools and materials, specimens, corrosion media, and inhibitors; immersion of specimens; testing of the corrosion rate using the weight loss method; measuring $\mathrm{pH}$ and salinity; and calculating the efficiency of inhibition.

\section{Specimens Preparation}

ASTM A36 steel plate with a thickness of $3 \mathrm{~mm}$ cut to a size of $30 \mathrm{~mm} \times 30 \mathrm{~mm}$ (Figure-1). The plate then drilled into the center of the specimen. The hole serves as a place to hang the specimen. The specimen scrubbed with a bristled brush to remove the coating layer and oxide layer on the specimen surface. In the specimen pickling stage, the specimens are immersed in $\mathrm{HCl}$ solution for about 10 minutes, then rinsed with clean water and brushed. The specimens were immersed in $\mathrm{NaOH}$ solution, then rinsed with water and dried [8]. The ready specimens are then photographed. Finally, the specimens were weighed using digital scales for initial weight data on the weight loss corrosion rate test [9].

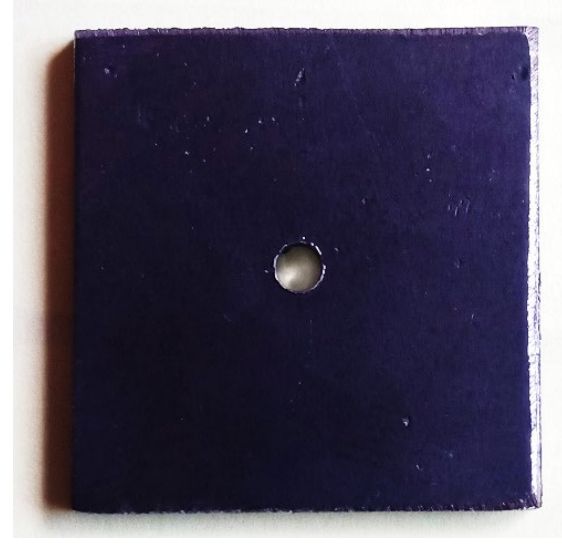

Figure-1. ASTM A36 steel speciment

\section{Corrosion Media Preparation}

The corrosion media used was a mixture of sodium chloride $(\mathrm{NaCl}) 3.5 \%$ and acetic acid $\left(\mathrm{CH}_{3} \mathrm{COOH}\right)$ $3 \%$. $3.5 \% \mathrm{NaCl}$ solution is made from 35 grams of $\mathrm{NaCl}$ mixed with aquadest until the volume reaches $1000 \mathrm{ml} .3 .5 \%$ $\mathrm{NaCl}$ solution was put into $200 \mathrm{ml}$ plastic cups each. $\mathrm{CH}_{3} \mathrm{COOH}$ is used as a mixture of corrosion media because the chitosan inhibitor can dissolve well in the acid solution acetate $\left(\mathrm{CH}_{3} \mathrm{COOH}\right) 3 \%$ [10]. So, to generalize environmental conditions, $12 \mathrm{ml}$ of $\mathrm{CH}_{3} \mathrm{COOH} 3 \%$ was added to all plastic cups in each glass.

\section{Inhibitor Preparation}

Natural inhibitor in the form of chitosan is made from milkfish scales and tiger shrimp shells waste. The making of chitosan refers to the manufacturing procedure of [11]. The production of chitosan consists of three stages, namely:

1. Deproteination

Milkfish scale and tiger shrimp shells powder of 80 gram was immersed in $3 \% \mathrm{NaOH}$ solution dissolved in $1000 \mathrm{ml}$ aquadest, then heated using a hotplate at $80^{\circ} \mathrm{C}$ for 2 hours while stirring. The solution is filtered and washed to a neutral $\mathrm{pH}[11]$.

2. Demineralization

The result of the deproteination process is added with $1 \mathrm{M} \mathrm{HCl}(1 \mathrm{M}=84 \mathrm{ml})$ dissolved in $1000 \mathrm{ml}$ aquadest, then heated at $75^{\circ} \mathrm{C}$ for 1 hour while stirring. The solution was filtered and the residue obtained was washed to a neutral $\mathrm{pH}$, then dried using an oven at $80^{\circ} \mathrm{C}$ for 24 hours. This demineralization process produces chitin [11].

3. Deacetylation

Chitin resulted from the previous process was added with $50 \% \mathrm{NaOH}$ dissolved in $1000 \mathrm{ml}$ of aquadest, then heated at $75^{\circ} \mathrm{C}$ while stirring. The solution is filtered and washed to a neutral $\mathrm{pH}$. The residue obtained was dried using an oven at $80^{\circ} \mathrm{C}$ for 24 hours. This deacetylation process produces chitosan [11].

Chitosan that has been obtained is then mixed with astetic acid $\left(\mathrm{CH}_{3} \mathrm{COOH}\right) 3 \%$. The variations in the concentration of chitosan inhibitors were $60 \mathrm{ppm}, 500$ $\mathrm{ppm}$ and $1000 \mathrm{ppm}$. The negative control in this study was without the addition of an inhibitor, while the positive control used sodium nitrite $1000 \mathrm{ppm}$.

\section{Corrosion Rate Testing with the Weight Loss Method}

This experiment used the weight loss method to determine the value of the corrosion rate on ASTM A36 steel. Previously, the specimens were prepared, their surface area was calculate and their initial weight was weighed, immersed in a mixture of $\mathrm{NaCl} 3.5 \%$ and $\mathrm{CH}_{3} \mathrm{COOH} 3 \%$ without and with the addition of an inhibitor for 4 weeks. Weight data collection was carried out once every 1 week of immersion.

\section{Data Analysis}

Percentage of chitin and chitosan was calculated using Equation (1) [10]. The corrosion rate is calculated using the weight loss calculation formula (Equation (2)) [9].

$$
\begin{aligned}
& \text { Percentage }(\%)=\frac{\text { weight of chitin } / \text { chitosan }}{\text { weight of sample }} \times 100 \% \\
& C R=K \frac{W}{D \times A \times T}
\end{aligned}
$$

where $C R$ is corrosion rate (mmpy), $W$ is mass loss ( $\mathrm{g}$ ), A is surface area of specimen $\left(\mathrm{cm}^{2}\right), T$ is time of exposure (hours), $D$ is density of specimen $\left(\mathrm{g} / \mathrm{cm}^{3}\right)$, and $K$ is a constant $\left(8,76 \times 10^{4}\right)$.

Percentage of inhibition efficiency with the weight loss method calculated using Equation (3) [12].

$\% E I=\frac{C R_{\text {uninhibited }}-C R_{\text {inhibited }}}{C R_{\text {uninhibited }}} \times 100 \%$

where $\% \mathrm{EI}$ is inhibition efficiency $(\%), C R_{\text {uninhibited }}$ is corrosion rate on corrosive media without inhibitor, and $C R_{\text {inhibited }}$ is corrosion rate in corrosive media with the addition of inhibitors. 


\section{RESULTS AND DISCUSSIONS}

Chitosan from Milkfish Scales and Tiger Shrimp Shells Chitosan in this research was utilized as an inhibitor of ASTM A36 steel in a mixture of $\mathrm{NaCl} 3.5 \%$ and $\mathrm{CH}_{3} \mathrm{COOH} 3 \%$ solutions. The synthesis of chitosan was carried out based on the research procedures of [11]. Powder of milkfish (Chanos chanos) scales and tiger shrimp (Panaeus monodon) shells were extracted into chitin through deproteination and demineralization processes. The next process is that chitin is synthesized into chitosan through deastelization process. Chitosan from milkfish scales is a brownish white powder. Black tiger shrimp shell chitosan is a light brown powder with a slightly orange color. The chitosan powder from milkfish scales is smaller than the chitosan produced from tiger shrimp shells.

Based on the data in Table-1, it is known that the percentage of chitin from tiger shrimp shells has a greater value than chitin from milkfish scales. This is because milkfish scales contain $45.07 \%$ protein [13] while tiger shrimp shells contain $14.85 \%$ protein [14]. The protein content in the large milkfish scales makes the initial weight decrease quite a lot because in the deproteination process, the protein contained in the milkfish scales will dissolve in the base. The initial weight decreased quite a lot, making the percentage of chitin yield has a smaller value than the chitin yield from tiger shrimp shells.

Table-1. Percentage of chitin and chitosan from milkfish scales and tiger shrimp shells wastes.

\begin{tabular}{|c|c|c|}
\hline & Milkfish Scales & $\begin{array}{c}\text { Tiger Shrimp } \\
\text { Shells }\end{array}$ \\
\hline Chitin (\%) & 55 & 83.75 \\
\hline Chitosan (\%) & 31.81 & 67.16 \\
\hline
\end{tabular}

Deacetylation process using a strong base and heat resulting in the loss of an acetyl groups on the causes of chitin chitosan charged positive so that it dissolves in acidic solutions such as acetic acid. The yield percentage of chitosan from tiger shrimp shells was $67.16 \%$, this result was in accordance with the research that the previously, the percentage of shrimp shell chitosan was $67.08 \%$ [10].

\section{The Effect of Addition of Inhibitors on the Corrosion Rate of ASTM A36 Steel}

Average data of the corrosion parameters on ASTM A36 steel in a mixture of $\mathrm{NaCl} 3.5 \%$ and $\mathrm{CH}_{3} \mathrm{COOH} 3 \%$ solutions shown in Table-2 to Table-5. Based on Table-2 it can be seen that 1 week immersion the smallest corrosion rate value is in the addition of chitosan from tiger shrimp shell with a concentration of $500 \mathrm{ppm}$ of 0.21482 mmpy, as also shown in Figure-2. Immersion 2 weeks, the lowest corrosion rate value is in the addition of chitosan from tiger shrimp shell with a concentration of 60 ppm of 0.16881 mmpy. Immersion 3 weeks, value lowest corrosion rate was in the addition of $60 \mathrm{ppm}$ of chitosan from milkfish scales of 0.12119 mmpy. Immersion 4 weeks, the lowest corrosion rate was the addition of 60 ppm of chitosan from milkfish scales with a value of 0.10995 mmpy.
The inhibitor of chitosan from tiger shrimp skin and chitosan from milkfish scales with a concentration of $60 \mathrm{ppm}$ and $500 \mathrm{ppm}$ had an average corrosion rate lower than the corrosion rate value of chitosan with a concentration of $1000 \mathrm{ppm}$. This shows that chitosan from milkfish scales and chitosan from tiger shrimp shells have the optimum concentration to inhibit the corrosion rate, so that when the inhibitor added to the corrosive medium exceeds the optimum concentration, the inhibitor will experience saturation or may experience the release of corrosion inhibitors [15].

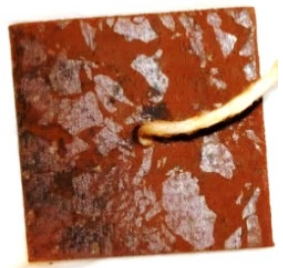

Figure-2. Specimen with chitosan inhibitor after immersion for one week

Data in Table-2 shows that the value of the corrosion rate on ASTM A36 steel with a salinity of 27.16 ppt is 0.28499 mmpy, a salinity of 28,70 ppt is 0.31470 mmpy and a salinity of $30.20 \mathrm{ppt}$ is $0.50804 \mathrm{mmpy}$. It can be seen that the greater the salinity of the corrosion media, getting greater to the value of the corrosion rate [16].

Table-2. Average data of corrosion parameters on ASTM A36 steel in a mixture of $\mathrm{NaCl} 3.5 \%$ and $\mathrm{CH}_{3} \mathrm{COOH} 3 \%$ solutions immersion 1 week

\begin{tabular}{|l|r|c|c|c|c|}
\hline \multicolumn{7}{|c|}{ 1 Week } \\
\hline Inhibitor & $\begin{array}{c}\text { Conc. } \\
\text { (ppm) }\end{array}$ & $\begin{array}{c}\text { (W-W') } \\
\text { (g) }\end{array}$ & $\begin{array}{c}\text { CR } \\
\text { (mmpy) }\end{array}$ & Sal. & pH \\
\hline $\begin{array}{l}\text { Control } \\
\text { negative* }\end{array}$ & 0 & 0.1667 & 0.50804 & 30.20 & 5.63 \\
\hline $\begin{array}{l}\text { Chitosan } \\
\text { milkfish } \\
\text { scales }\end{array}$ & 60 & 0.0933 & 0.28499 & 27.16 & 5.67 \\
\cline { 2 - 6 } & 1000 & 0.0920 & 0.28642 & 28.36 & 5.67 \\
\hline $\begin{array}{l}\text { Chitosan } \\
\text { tiger } \\
\text { shrimp } \\
\text { shells }\end{array}$ & 60 & 0.1020 & 0.31747 & 28.70 & 5.63 \\
\cline { 2 - 6 } & 500 & 0.0700 & 0.31684 & 28.10 & 5.63 \\
\hline $\begin{array}{l}\text { Control } \\
\text { positive }\end{array}$ & 1000 & 0.0850 & 0.26118 & 29.16 & 5.67 \\
\hline \multicolumn{7}{|l|l|}{} & 1000 & 0.1046 & 0.31878 & 29.53 & 5.63 \\
\hline
\end{tabular}

Table-3. Average data of corrosion parameters on ASTM A36 steel in a mixture of $\mathrm{NaCl} 3.5 \%$ and $\mathrm{CH}_{3} \mathrm{COOH} 3 \%$ solutions immersion 2 weeks

\begin{tabular}{|l|r|c|c|c|c|}
\hline \multicolumn{7}{|c|}{ 2 Weeks } \\
\hline Inhibitor & $\begin{array}{c}\text { Conc. } \\
\text { (ppm) }\end{array}$ & $\begin{array}{c}\text { (W-W') } \\
\text { (g) }\end{array}$ & $\begin{array}{c}\text { CR } \\
\text { (mmpy) }\end{array}$ & Sal. & pH \\
\hline $\begin{array}{l}\text { Control } \\
\text { negative* }\end{array}$ & 0 & 0.2227 & 0.34174 & 33.13 & 5.43 \\
\hline $\begin{array}{l}\text { Chitosan } \\
\text { milkfish } \\
\text { scales }\end{array}$ & 60 & 0.1173 & 0.18173 & 27.63 & 4.76 \\
\cline { 2 - 6 } & 500 & 0.1260 & 0.19378 & 29.47 & 4.76 \\
\hline $\begin{array}{l}\text { Chitosan } \\
\text { tiger } \\
\text { shrimp } \\
\text { shells }\end{array}$ & 60 & 0.1207 & 0.18816 & 29.23 & 4.87 \\
\cline { 2 - 6 } $\begin{array}{l}\text { Control } \\
\text { positive }\end{array}$ & 1000 & 0.1093 & 0.16881 & 27.17 & 4.67 \\
\cline { 2 - 6 } & 1000 & 0.1227 & 0.21111 & 29.67 & 5.17 \\
\hline
\end{tabular}


The media without the addition of an inhibitor has a $\mathrm{pH}$ of 5.43 with a corrosion rate value of 0.34174 mmpy. Media with the addition of $1000 \mathrm{ppm}$ sodium nitrit has a $\mathrm{pH}$ of 4.87 with a corrosion rate value of 0.18774 mmpy. Media with the addition of 60 ppm milkfish scales chitosan has a $\mathrm{pH}$ of 4.76 with a corrosion rate value of 0.18173 mmpy and media with the addition of $60 \mathrm{ppm}$ chitosan from tiger shrimp shells has a $\mathrm{pH}$ of 4.67 with a corrosion rate value of 0.16881 mmpy (Table-3). These results are inversely proportional to the statement of [17] which states that the corrosion rate will increase at $\mathrm{pH}<7$ and $\mathrm{pH}>13$.

This difference is because chitosan can work at an acidic $\mathrm{pH}$, so with a lower $\mathrm{pH}$ than corrosive media without the addition of an inhibitor, the corrosion rate produced by the addition of a chitosan inhibitor will have a smaller value. This is in accordance with the statement of [12] which states that at $\mathrm{pH} 6$ chitosan begins to dissolve, making it easier for the functional groups in the form of $-\mathrm{OH}$ and $-\mathrm{NH}_{2}$ to bind to the steel surface.

Apart from $\mathrm{pH}$ and salinity, dissolved solids are also a factor affecting the corrosion rate. This research used corrosive media in the form of a mixture of sodium chloride $(\mathrm{NaCl}) 3.5 \%$ and acetic acid $\left(\mathrm{CH}_{3} \mathrm{COOH}\right) 3 \%$ solutions. Chloride $(\mathrm{Cl})$ attacks mild steel and stainless steel layers. This solid chloride $(\mathrm{Cl})$ causes pitting corrosion, crevice corrosion and can also cause the breakdown of alloys [17].

Table-4. Average data of corrosion parameters on ASTM A36 steel in a mixture of $\mathrm{NaCl} 3.5 \%$ and $\mathrm{CH}_{3} \mathrm{COOH} 3 \%$ solutions immersion 3 weeks

\begin{tabular}{|l|r|r|r|r|r|}
\hline \multicolumn{7}{|c|}{ 3 Weeks } \\
\hline Inhibitor & $\begin{array}{c}\text { Conc. } \\
(\mathbf{p p m})\end{array}$ & $\begin{array}{c}\text { (W-W') } \\
(\mathbf{g})\end{array}$ & $\begin{array}{c}\text { CR } \\
(\mathbf{m m p y})\end{array}$ & Sal. & pH \\
\hline $\begin{array}{l}\text { Control } \\
\text { negative* }\end{array}$ & 0 & 0.2327 & 0.23739 & 33.87 & 5.13 \\
\hline $\begin{array}{l}\text { Chitosan } \\
\text { milkfish } \\
\text { scales }\end{array}$ & 60 & 0.1193 & 0.12119 & 28.10 & 5.17 \\
\cline { 2 - 6 } & 500 & 0.1433 & 0.14768 & 29.90 & 5.03 \\
\hline $\begin{array}{l}\text { Chitosan } \\
\text { tiger } \\
\text { shrimp } \\
\text { shells }\end{array}$ & 1000 & 0.1407 & 0.14480 & 30.30 & 5.07 \\
\cline { 2 - 6 } & 500 & 0.1513 & 0.15528 & 27.70 & 4.93 \\
\hline $\begin{array}{l}\text { Control } \\
\text { positive }\end{array}$ & 1000 & 0.1447 & 0.14784 & 31.00 & 4.80 \\
\hline
\end{tabular}

Table-5. Average data of corrosion parameters on ASTM A36 steel in a mixture of $\mathrm{NaCl} 3.5 \%$ and $\mathrm{CH}_{3} \mathrm{COOH} 3 \%$ solutions immersion 4 weeks

\begin{tabular}{|l|r|r|r|r|r|}
\hline \multicolumn{7}{|c|}{ 4 Weeks } \\
\hline Inhibitor & $\begin{array}{c}\text { Conc. } \\
\text { (ppm) }\end{array}$ & $\begin{array}{c}\text { (W-W') } \\
\text { (g) }\end{array}$ & $\begin{array}{c}\text { CR } \\
(\mathbf{m m p y})\end{array}$ & Sal. & pH \\
\hline $\begin{array}{l}\text { Control } \\
\text { negative* }\end{array}$ & 0 & 0.2433 & 0.18568 & 32.50 & 4.83 \\
\hline $\begin{array}{l}\text { Chitosan } \\
\text { milkfish } \\
\text { scales }\end{array}$ & 60 & 0.1433 & 0.10995 & 27.17 & 4.93 \\
\cline { 2 - 6 } & 500 & 0.1967 & 0.15257 & 31.10 & 4.57 \\
\hline $\begin{array}{l}\text { Chitosan } \\
\text { tiger } \\
\text { shrimp } \\
\text { shells }\end{array}$ & 60 & 0.1873 & 0.14511 & 30.70 & 4.43 \\
\cline { 2 - 6 } & 500 & 0.1940 & 0.13277 & 28.10 & 4.60 \\
\hline $\begin{array}{l}\text { Control } \\
\text { positive** }\end{array}$ & 1000 & 0.1893 & 0.14610 & 33.30 & 4.50 \\
\hline
\end{tabular}

Control negative* $=$ Without inhibitor

Control positive $^{* *}=$ Sodium nitrit $1000 \mathrm{ppm}$
Inhibition Efficiency of Chitosan from Milkfish Scales and Chitosan from Tiger Shrimp Shells

The value inhibition efficiency of chitosan from milkfish scales, chitosan from tiger shrimp shells and sodium nitrit starting from 1 week to 4 weeks of immersion can be seen in Table- 6 . The optimum inhibition efficiency at 1 week of immersion using chitosan from tiger shrimp shells concentration is $500 \mathrm{ppm}$ with a value of $57.7 \%$. Immersion for 2 weeks the optimum inhibition efficiency using chitosan from tiger shrimp shells with a concentration of $60 \mathrm{ppm}$ with a value of $51 \%$. Immersion for 3 weeks the optimum inhibition efficiency using chitosan from milkfish scales concentration is $60 \mathrm{ppm}$ with a value of $48.9 \%$. Immersion 4 weeks, optimum inhibition efficiency using chitosan from milkfish scales concentration is $60 \mathrm{ppm}$ with a value of $40.8 \%$.

Inhibition efficiency in milkfish scales chitosan with a concentration of $500 \mathrm{ppm}$ and $1000 \mathrm{ppm}$ has a lower value than the inhibition efficiency of a concentration of $60 \mathrm{ppm}$. This is in accordance with the research results of [18] which states that the highest inhibition efficiency value is produced by an inhibitor with a concentration of $100 \mathrm{ppm}$ while for a concentration of $200 \mathrm{ppm}, 300 \mathrm{ppm}$ and $400 \mathrm{ppm}$ continues to decrease in efficiency. The inhibition efficiency is in accordance with the corrosion rate (mm/year) value of ASTM A36 which has the lowest corrosion rate value produced by specimens with an inhibitor concentration of $100 \mathrm{ppm}$ [18].

The inhibition efficiency of chitosan from tiger shrimp shells increased and reached its optimum at a concentration of $500 \mathrm{ppm}$ but decreased the efficiency value at a concentration of $1000 \mathrm{ppm}$ (Table-6). This is in accordance with the statement of [7] which states that the addition of Water Soluble Chitosan (WSC) of 10-1300 $\mathrm{mg} / \mathrm{L}$ can block the surface where corrosion occurs so that it inhibits the metal dissolving process while the addition of WSC of $1500 \mathrm{mg} / \mathrm{L}$ occurs diffusion of inhibitors into the solution so that inhibition efficiency decreases.

Sodium nitrite is one type of synthesis inhibitor. Sodium nitrite in this research was used as a positive control. Sodium nitrite very effective to inhibit the corrosion of steel reinforcement which is contaminated with chloride [19]. The data from Table 6 shows that the efficiency of the sodium nitrite with a concentration of $1000 \mathrm{ppm}$ has a lower efficiency value when compared to the chitosan from milkfish scales and chitosan from tiger shrimp shells with a concentration of 1000 ppm within 1 week to 3 weeks of immersion time. This is because the corrosive solutions used in this research are acidic and chitosan inhibitors can work better at low $\mathrm{pH}$ or acidic ones [12] while sodium nitrite inhibitors can work well in neutral or alkaline conditions [19].

The inhibition efficiency value of chitosan from milkfish scales and tiger shrimp shells has different values, although the percentage difference is not significant (Figure-3). This is because the ash content in the milkfish scales chitosan and tiger shrimp shells chitosan is not much different. Chitosan from milkfish scales contains an ash content of $1.15 \%$ [6] while chitosan from tiger shrimp shells contains an ash content of $0.99 \%$ [20]. The ash contained in chitosan from milkfish scales and tiger shrimp shells has a small value so that the chitosan has the same efficiency value or does not differ much in inhibiting the corrosion rate of the test specimens. [7]. 
Table-6. Percentage of inhibition efficiency from 1 to 4 weeks immersion

\begin{tabular}{|c|c|c|c|c|c|}
\hline \multirow{3}{*}{ Inhibitor } & \multirow{3}{*}{$\begin{array}{l}\text { Conc. } \\
\text { (ppm) }\end{array}$} & \multirow{2}{*}{\multicolumn{4}{|c|}{$\begin{array}{c}\text { Inhibition Efficiency (\%) } \\
\text { Immersion Week }\end{array}$}} \\
\hline & & & & & \\
\hline & & 1 & 2 & 3 & 4 \\
\hline \multirow{3}{*}{$\begin{array}{l}\text { Chitosan } \\
\text { milkfish scales }\end{array}$} & 60 & 43.9 & 46.8 & 48.9 & 40.8 \\
\hline & 500 & 43.6 & 43.3 & 37.8 & 17.8 \\
\hline & 1000 & 37.5 & 44.9 & 39 & 21.8 \\
\hline \multirow{3}{*}{$\begin{array}{l}\text { Chitosan tiger } \\
\text { shrimp shells }\end{array}$} & 60 & 37.6 & 51 & 34.6 & 28.5 \\
\hline & 500 & 57.7 & 38.2 & 37.7 & 19.6 \\
\hline & 1000 & 48.6 & 41.2 & 37 & 21.3 \\
\hline $\begin{array}{l}\text { Control } \\
\text { positive }^{* *}\end{array}$ & 1000 & 37.3 & 45.1 & 36.8 & 28.8 \\
\hline
\end{tabular}

Control positive $^{* *}=$ Sodium nitrit $1000 \mathrm{ppm}$

The insignificant comparison of the inhibition efficiency between milkfish scales chitosan and tiger shrimp shells, which is not too significant, can also be seen in the results of statistical analysis using the One Way ANOVA method. The results of the homogeneity test showed that the sig value of milkfish scales chitosan was 0.263 while the tiger shrimp shell chitosan sig value was 0.862 . The value of $\operatorname{sig}>$ a (0.05), it can be concluded that the chitosan of milkfish scales and tiger shrimp shells have the same or homogeneous variant values so that the prerequisites for using ANOVA are fulfilled [21]. ANOVA test results showed that the sig value of milkfish scales chitosan was 0.303 , while the chitosan value of tiger shrimp shell chitosan was 0.989 . The sig value $>0.05$ so it can be concluded that there is an average equation between the inhibition efficiency value of chitosan from milkfish scales and chitosan from tiger shrimp shells with a concentration of $60 \mathrm{ppm}, 500 \mathrm{ppm}$ and $1000 \mathrm{ppm}$ [21].

Inhibition efficiency for 4 weeks produced chitosan from milkfish scales is $60 \mathrm{ppm}$ is $45.1 \%$, concentration of $500 \mathrm{ppm} 36.6 \%$ and $1000 \mathrm{ppm} 35.8 \%$ with the total average value of the overall concentration is $38.8 \%$. The average value for $60 \mathrm{ppm}$ chitosan from tiger shrimp was $37.9 \%$, concentration of 500 ppm $38.3 \%$ and $1000 \mathrm{ppm} 37 \%$ with the overall average total concentration of $37.75 \%$. So, it can be concluded that when viewed from the overall average value of the concentration between chitosan from milkfish scales and tiger shrimp shells, it has almost the same value, only a difference of $1.05 \%$.

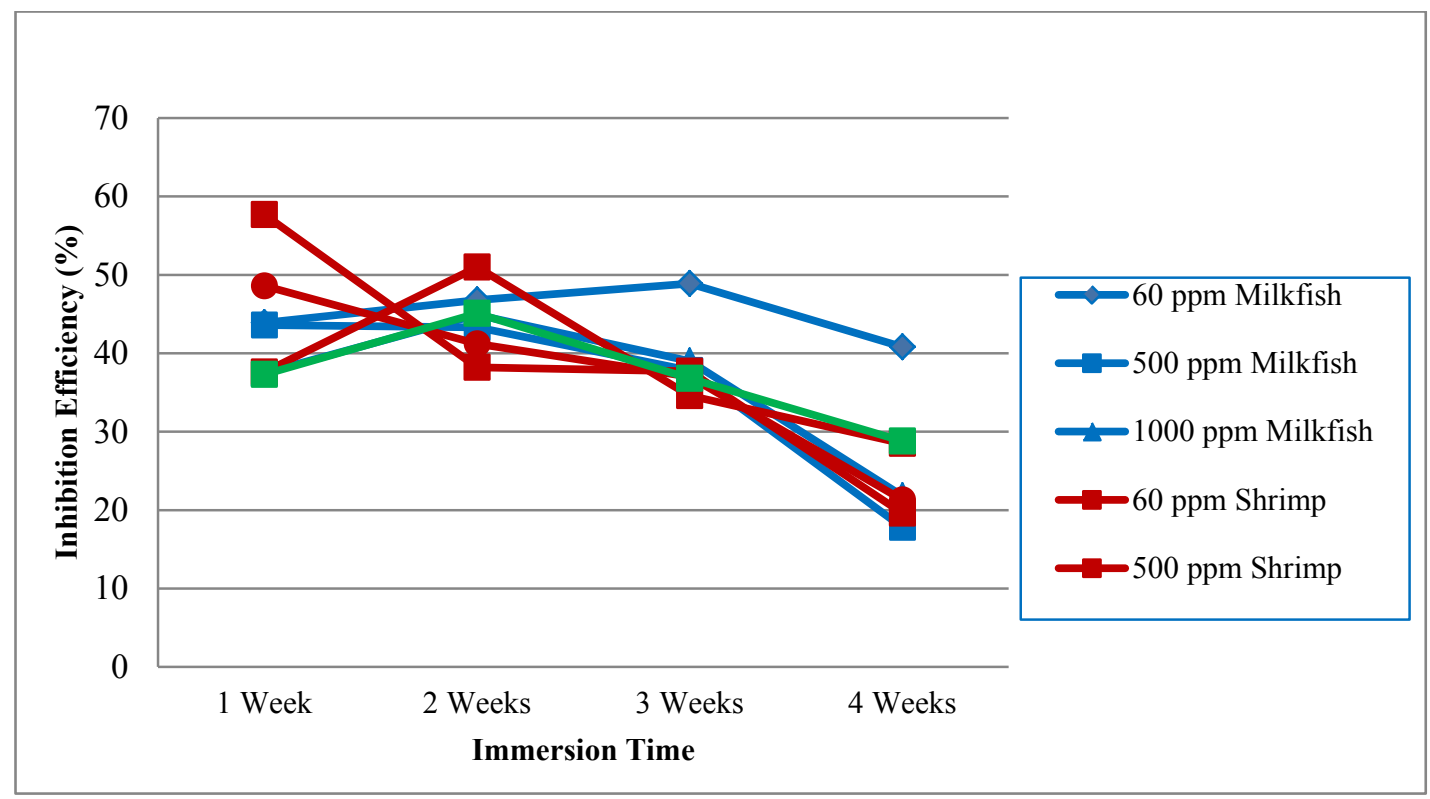

Figure-3. Inhibition efficiency of milkfish scales chitosan, tiger shrimp shell chitosan and sodium nitrite

\section{CONCLUSIONS}

Inhibition efficiency of chitosan from milkfish (Chanos chanos) scales as an inhibitor of corrosion rate on ASTM A36 steel consecutively starting from the first week of immersion to the fourth week is for a concentration of $60 \mathrm{ppm}$ were $43.9 \%, 46.8 \%, 48.9 \%$, $40.8 \%$; concentration of $500 \mathrm{ppm}$ were $43.6 \%, 43.3 \%$, $37.8 \%, 17.8 \%$; and a concentration of $1000 \mathrm{ppm}$ were $37.5 \%, 44.9 \%, \quad 39 \%, \quad 21.8 \%$. Meanwhile inhibition efficiency of chitosan from tiger shrimp (Panaeus monodon) shells as a corrosion rate inhibitor on ASTM A36 steel consecutively starting from the first week of immersion to the fourth week is for a concentration of 60 ppm were $37.6 \%, 51 \%, 34.6 \%, 28.5 \%$; concentration of $500 \mathrm{ppm}$ were $57.7 \%, 38.2 \%, 37.7 \%, 19.6 \%$; and a concentration of $1000 \mathrm{ppm}$ were $48.6 \%, 41.2 \%, 37 \%$, $21.3 \%$. The data shows inhibition efficiency between chitosan from milkfish scales and tiger shrimp shells has almost the same value, which is shows the similarity in the efficiency value and from the average value of the overall concentration from the first week to the fourth week between chitosan from milkfish scales $(38.8 \%)$ and tiger shrimp shells $(37.75 \%)$ has almost the same value, only the difference $1.05 \%$. 


\section{REFERENCES}

[1] Hasnidar \& Tamsil, A. 2019. Pengolahan Ikan Bandeng Tanpa Duri di Kelurahan Lakkang, Kecamatan Tallo, Kota Makassar. Jurnal Aplikasi Teknik dan Pengabdian Masyarakat. 3(1): 95-99. http://dx.doi.org/10.36339/je.v3i1.193

[2] Rahmat, A., Patdjai, A. B. \& Suwarjoyowirayatno. 2019. Studi Kualitas Fisika-Kimia dan Sensorik Udang Vaname (Litopenaeus vannamei) dengan Perlakuan Soaking Time Sebelum Pembekuan. Journal Fish Protech. 2(1): 46-58. http://dx.doi.org/10.33772/jfp.v2i1.6469

[3] Verma, Chandrabhan, M. A. Quraishi, K. Kluza, M. Makowska-Janusik, Lukman O. Olasunkanmi and Eno E. Ebenso. 2017. Corrosion inhibition of mild steel in $1 \mathrm{M} \mathrm{HCl}$ by D-glucose derivatives of dihydropyrido [2,3-d:6,5-d'] dipyrimidine-2, 4, 6, 8(1H,3H,5H,7H)-tetraone. Scientific Report. 7: 1-17. DOI: $10.1038 /$ srep44432

[4] Yanuar, A. P., Pratikno, H. \& Titah, H. S. 2016. Pengaruh Penambahan Inhibitor Alami terhadap Laju Korosi pada Material Pipa dalam Larutan Air Laut Buatan. Jurnal Teknik ITS. 5(2): 297-302. DOI: 10.12962/j23373539.v5i2.18938

[5] Sangeetha, Y., Meenakshi, S. \& Sundaram, C. S. 2016. Interactions at the mild steel acid solution interface in the presence of O-fumaryl-chitosan: Electrochemical and surface studies. Carbohydrate Polymers. 136: 38-45. https://doi.org/10.1016/j.carbpol.2015.08.057

[6] Bangngalino, H. \& Akbar, A. M. I. 2017. Pemanfaatan Sisik Ikan Bandeng sebagai Bahan Baku Kitosan dengan Metode Sonikasi dan Aplikasinya untuk Pengawet Makanan. Ujung Pandang. Prosiding Seminar Hasil Penelitian (SNP2M) Politeknik Negeri Ujung Pandang. pp. 105-108.

[7] Harmami, Ulfin, I., Sakinah, A. H. \& Ni'mah, Y. L. 2019. Water-soluble chitosan from shrimp and mussel shells as corrosion inhibitor on tinplate in $2 \%$ $\mathrm{NaCl}$. Malaysian Journal of Fundamental and Applied Sciences. 15(2): 212-217. https://doi.org/10.11113/mjfas.v15n2.972

[8] American Society for Testing and Materials (ASTM). G31-72. 2004. Standart Practice for Laboratory Immersion Corrosion Testing of Metals. West Conshohocken.

[9] American Society for Testing and Materials (ASTM). G1. 1999. Standart Practice for Preparing, Cleaning and Evaluation Corrosion Test Specimens. West Conshohocken.

[10] Agustina, S., Swantara, I. M. D. \& Suartha, I. N. 2015. Isolasi Kitin, Karakterisasi dan Sintesis Kitosan dari Kulit Udang. Jurnal Kimia. 9(2): 271278.

https://doi.org/10.24843/JCHEM.2015.v09.i02.p19

[11] Sulistijowati, R., Mile, L. \& Wulandari, K. 2014. Aktivitas Antibakteri Kitosan Kulit Udang Vaname (Litopenaeus vannamei) Terhadap Bakteri Kontaminan Bakso Ikan Tuna (Thunnus sp.). Jurnal Jurusan Teknologi Hasil Perikanan Fakultas Perikanan dan Ilmu Kelautan Universitas Negeri Gorontalo. pp. 1-7.
[12] Erna, M., Emriadi, Alif, A. \& Arief, S. 2011. Efektifitas Kitosan sebagai Inhibitor Korosi pada Baja Lunak dalam Air Gambut. Jurnal Natur Indonesia. $\quad 13(2)$ : $118-122$. http://dx.doi.org/10.31258/jnat.13.2.118-122

[13] Fajari, C. N. A., Yusuf, M. \& Nurrahman. 2019. Pengaruh Penggunaan Sisik Ikan Bandeng terhadap Kadar Kalsium Daya Kembang dan Organoleptik Camilan Stick. Jurnal Pangan dan Gizi. 9 (1): $65-$ 73. https://doi.org/10.26714/jpg.9.1.2019.65-73

[14] Kaimudin, M. \& Leounupun, M. F. 2016. Karakterisasi Kitosan dari Limbah Udang dengan Proses Bleaching dan Deasetilasi yang Berbeda. Majalah Biam. 12(1): 1-7.

[15] Gapsari, F., Soenoko, R., Suprapto, A. \& Wahyono, S. 2015. Bee Wax Propolis Extract as Eco-Friendly Corrosion Inhibitors for 304SS in Sulfuric Acid. International Journal of Corrosion. pp. 1-10. https://doi.org/10.1155/2015/567202

[16] Purnawati, R., Jokosisworo, S. \& Yudo, H. 2020. Pengaruh Salinitas Air Laut Terhadap Laju Korosi Baja SS 400 pada Kapal. Jurnal Teknik Perkapalan. 8(2): 175-181.

[17] Sidiq, M. F. 2013. Analisa Korosi dan Pengendaliannya. Jurnal Foundry. 3(1): 25-30.

[18] Hidayatullah, S., Gapsari, F. \& Setyarini, P. H. 2019. Perilaku Korosi Besi ASTM A36 pada Asam Klorida $(\mathrm{HCl})$ dengan Inhibitor Kitosan Sisik Ikan. Prosiding Seminar Nasional Inovasi dan Aplikasi Teknologi di Industri (SENIATI). 5(1): 336-342.

[19] Nikitasari, A., Anwar, M. S., Mabruri, E. \& Sundjono. 2014. Evaluasi Inhibitor Sodium Nitrit di Dalam Larutan Beton Sintetis. Jurnal Sains Materi Indonesia. $\quad 16(1)$ : $12-18$. http://dx.doi.org/10.17146/jsmi.2014.16.1.4327

[20] Cahyono, E. 2018. Karakteristik Kitosan dari Limbah Cangkang Udang Windu (Panaeus monodon). Jurnal Akuatika Indonesia. 3(2): 96-102. https://doi.org/10.24198/jaki.v3i2.23395

[21] Setyawarno, D. 2016. Panduan Statistik Terapan untuk Penelitian Pendidikan: Analisis Data Penelitian dalam Pendidikan dengan Aplikasi SPSS Versi 22. Pendidikan IPA FMIPA UNY. Yogyakarta 